\title{
THE LIVED EXPERIENCES OF LATE-ADOLESCENT FEMALE SUICIDE SURVIVORS: 'A PART OF ME DIED'
}

\section{Authors:}

Willem A. Hoffmann ${ }^{1}$

Chris Myburgh ${ }^{2}$

Marie Poggenpoel $^{3}$

\author{
Affiliations: \\ ${ }^{1}$ Department of \\ Biomedical Sciences, \\ Tshwane University of \\ Technology, South Africa
}

${ }^{2}$ Department of

Educational Psychology,

University of

Johannesburg,

South Africa

${ }^{3}$ Department of Nursing Sciences, University of

Johannesburg,

South Africa

Correspondence to:

Willem Hoffmann

email:

hoffmannwa@tut.ac.za

Postal address:

Department of Biomedical

Sciences, Tshwane

University of Technology,

Private Bag X680, Pretoria

0001, South Africa

\section{Keywords:}

phenomenology;

postvention;

psychoeducation;

qualitative analysis;

suicide aftermath

\section{Dates:}

Received: 31 Aug. 2009

Accepted: 25 Feb. 2010

Published: 08 June 2010

How to cite this article:

Hoffmann, W.A.,

Myburgh, C. \&

Poggenpoel, M., 2010,

'The lived experiences of late-adolescent female suicide survivors: "A part of me died"', Health SA Gesondheid 15(1), Art \#493, 9 pages. DOI: $10.4102 /$ hsag.v15i1.493

This article is available at: http://www.hsag.co.za

\section{(c) 2010. The Authors.}

Licensee: OpenJournals Publishing. This work is licensed under the

Creative Commons

Attribution License.

\section{ABSTRACT}

People's thoughts often focus on the suicide victim immediately after a completed suicide. Yet, the real victims of such an event are those individuals who are left behind to cope with the aftermath of the suicide. This phenomenological psychological study explored the lived experiences of lateadolescent suicide survivors, particularly those negative experiences that seemed to worsen in the weeks and months after a significant other's completed suicide. The research participants were five female late-adolescents (aged 17-22 years) who were recruited by means of purposive sampling at a South African tertiary institution and at youth camps. Data collection consisted of collagefacilitated, face-to-face phenomenological interviews. In addition, some participants provided documentary material in the form of personal diaries, letters and poems. The data analysis was conducted according to Giorgi's phenomenological method. The following salient experiences emerged during the data analysis: guilt, self-blame, blaming others or God, anger, loss or restriction of 'self', depression, suboptimal behavioural coping patterns, changes in relationship dynamics, and suicidality. The results of this study can be used by mental health professionals and caregivers to support adolescent suicide survivors effectively, in the midst of their mourning.

\section{OPSOMMING}

Mense se gedagtes fokus meestal op die selfmoordslagoffer onmiddellik na ' $n$ voltooide selfmoord. Tog is die werklike slagoffers die persone wat agterbly om die lewe na die selfmoord te hanteer. Hierdie fenomenologies-sielkundige studie het die geleefde belewenisse van laat-adolessente oorlewendes ondersoek, spesifiek daardie negatiewe belewenisse wat skynbaar erger word in die weke en maande na 'n betekenisvolle ander se voltooide selfmoord. Die navorsingsdeelnemers was vyf vroulike laat-adolessente (17-22 jaar oud) wat gewerf is deur middel van doelgerigte selektering by 'n Suid-Afrikaanse tersiêre instelling en jeugkampe. Data-insameling het geskied aan die hand van collage-gefasiliteerde, aangesig-tot-aangesig fenomenologiese onderhoude. Sommige deelnemers het addisionele dokumente in die vorm van persoonlike dagboeke, briewe en gedigte beskikbaar gestel vir data-analise. Die data is geanaliseer volgens Giorgi se fenomenologiese metode. Die volgende belewenisse het na vore getree tydens die data-analise: skuldgevoelens, self-blaam/spyt, blameer ander/God, woede, verlies/inperking van 'self', depressie, sub-optimale gedragshanteringspatrone, veranderinge in verhoudingsdinamika, en selfmoordneigings. Die resultate van hierdie studie kan deur geestesgesondheidwerkers en versorgers aangewend word om adolessente selfmoordagtergeblewenes effektief te ondersteun in die rouproses.

\section{INTRODUCTION}

... compare the act of suicide to that of a stone tossed into a pond. The splash may be large or small. It always sends ripples in every direction, in a concentric washing of every floating leaf, twig, and waterbug. The stone sinks out of sight, but its impact is felt by the widening ripples which touch distant, unfamiliar territory. We are startled, tossed about; without control, we hang on and ride the dizzying waves. If we choose not to stay afloat, we too might sink.

(Bolton 1987:90-91)

Suicide is an inexplicable, irreversible and tragic act that often leaves people confused and stigmatised. Those who have completed suicide can no longer be probed about their motives, thoughts or emotions leading to the eventual act. Immediately after the suicide, most people's thoughts focus on the person who has died. Yet, the ultimate sufferers in this tragedy are those individuals who are left behind to cope with the emotional trauma of losing a significant other, of struggling with many unanswerable questions, self-blaming and an inability to move on with their lives (Cvinar 2005:17-19). Suicide is a traumatic event that tends to elicit a complex array of physical, psychological and social reactions (Cerel, Jordan \& Duberstein 2008:39-41; Feigelman \& Feigelman 2008:285-287). The situation is often made more complex by a society that does not sanction open discussion of the suicide and the associated negative emotions towards the victim (Cvinar 2005:18).

Suicide is a significant cause of death globally. Statistics indicate that, on average, more people die annually from suicide than from war, homicide or traffic accidents. As such, it has very serious mental health implications for a relatively large part of the population (Schlebusch 2005:35-39; Sudak, Maxim \& Carpenter 2008:136). Conservatively, an estimated six survivors (individuals who have experienced the death by suicide of a significant other) are intimately affected by each completed suicide (Cvinar 2005:15; McIntosh 1996:148).

Although much information regarding the demographics, causes, risk factors and treatment of suicidal behaviour has been revealed over the past four decades, only a few studies, most of which were conducted in the United States of America, have focused on the lived experiences of suicide survivors (AFSP Workshop 2003; Barrett \& Scott 1990:1-2; Seeber 2002:32). As a result, mental health professionals and other caregivers have limited access to qualitative information and guidelines to meet the needs 
of suicide survivors (McMenamy, Jordan \& Mitchell 2008:385). What is largely missing from current literature on suicide survivors, in particular, are the voices of adolescent survivors, as well as an understanding of their lived experiences which influence their coping and adaptation to a life without the suicide victim (Cerel et al. 2008:41).

In a survey study among South African tertiary students, Hoffmann (2002:50-52) found that a high number (73.8\%) of female students had experienced one or more traumatic events during the preceding year. The most frequent traumatic event reported was the death of a significant other by means of either motor vehicle accidents or suicide. In the light of these findings, we decided in this project to focus on the lived experiences of late-adolescent female suicide survivors in the aftermath of a significant other's completed suicide. ${ }^{1}$ Three experience clusters emerged from the data analysis, namely, (1) lived experiences that seem to worsen with time, (2) 'disorganisation' lived experiences that involved a struggle to cope and/or adapt to a changed life and (3) 'healing' lived experiences that involved the effective integration and adaptation to a changed life. The 'disorganisation' lived experience cluster has already been reported elsewhere (Hoffmann 2007:431-444) and included the following seven lived experiences: empty and frozen time, longing to understand the reason/s for the suicide, frustrations, emotional pain, changes in family dynamics, ineffective social support, and unanswerable questions. This article focuses specifically on those negative lived experiences that seemed to worsen in the weeks and months after the suicide event (Hoffmann 2004:112). A better understanding of these experiences can be used, ultimately, to provide well-informed psychoeducation and effective postvention interventions to lateadolescent suicide survivors.

\section{RESEARCH METHOD AND DESIGN}

\section{Research approach and method}

The researchers chose a qualitative, descriptive, explorative and contextual research strategy with both a phenomenological psychology and an arts-based research approach to inquiry (Creswell 1998:15-18). A phenomenological psychology research approach focuses on the psychological meanings of research participants' lived experiences in their particular life worlds (Giorgi 1997:252-254; Kruger 1988:37-38). An arts-based research approach involves the use of aesthetic qualities and artistic media in research endeavours to give expression to lived experiences, emotions and thoughts (Springgay 2002:12-13, 24).

\section{Recruitment of participants}

Female late adolescents at a tertiary academic institution in Pretoria, South Africa, were invited by the first author to participate in the study by means of posters, information leaflets and short oral presentations at student residence meetings, as well as through a news flash on the university's electronic internal news page. Formal permission to approach potential research participants in these settings was granted by the dean, residence managers and house committee chairpersons concerned. Purposive sampling was used to recruit only those individuals who had experienced a specific phenomenon and that could provide rich, naïve descriptions of the phenomenon under investigation (Schurink 1998:253-254).

The inclusion criteria were as follows:

- participants must have personally experienced the loss of a significant other to suicide - 'significant other' being described in the information leaflet as 'someone close to you, for example, a good friend or close relative'

- the most recent suicide event in their lives should not have occurred within the 6-month period prior to the phenomenological interview

1.This research was conducted as part of the first author's doctoral studies unde supervision of the second and third authors at the Rand Afrikaans University, South Africa (Hoffmann 2004).
- female individuals

- late adolescents (aged 17-22 years) (Thom et al. 1998:385).

Five individuals who met all the inclusion criteria were eventually recruited to participate in the study. The following strategies were employed to ensure adequate data saturation (Morse 1995:147-149; Morse 2000:3):

- the topic of the study was formulated in such a way as to be sufficiently clear, narrow and specific

- a cohesive participant sample were selected through the use of specific and clearly delineated inclusion criteria

- rich, high-quality data were collected by means of collagefacilitated phenomenological interviews and additional documentary material.

\section{Data collection}

The primary data collection method was that face-to-face phenomenological interviews conducted by the first author (Laverty 2003:18). The interviews were conducted in Afrikaans or English and lasted between $42 \mathrm{~min}$ and $63 \mathrm{~min}$ each. They were audio-recorded with the research participants' permission and transcribed verbatim by the first author. The specific research question that guided the phenomenological interviews was as follows:

Tell me the story of how you experienced the suicide of someone close to you, for example, a good friend or close relative? Also, tell me how you coped or made sense of this experience since it happened?

Each research participant was requested to create a collage of her lived experiences before the actual interview/s. They were each provided with a standard white page $(51 \mathrm{~cm} \times 64 \mathrm{~cm})$ on which to create a collage of their choice. The collage could, inter alia, include personal photos, magazine pictures, drawings, written words or poems. The aims of the collage were to serve as narrative facilitator during the phenomenological interview, to provide each participant with a rich personal symbolic vocabulary and reflective insight during the interview, and to facilitate the recall of vivid memories of the lived experiences (Radley \& Taylor 2003:79; Turner 2003). All the research participants gave permission to the first author to keep the collages permanently and scan them electronically for research purposes.

Documentary materials such as diaries and letters can be very informative texts of in-depth lived experiences. The personal and confidential style of such texts often transcends the social barriers for the description of stigmatised experiences that may be encountered in a face-to-face interview situation (Harris 2002:2-5). In this study, one participant granted us access to undated diary notes that were written over a two-year period around her mother's completed suicide.

\section{Data analysis}

The data analysis was conducted according to Giorgi's phenomenological method (1985:10-21; 1989:44-59; 1997:243249 ) because of its strong psychological sensitivity. In addition, some analysis principles from the phenomenological approaches of Kruger (1988:152-156) and Wertz (1985:164-167, 177) were integrated with Giorgi's method to further strengthen and support its psychological inclinations. The following four basic data analysis steps were followed:

- Step 1: Get a holistic sense of the whole text by reading the entire text with an open mind, to understand the language and experiences of the participant.

- Step 2: Read through the text with the specific aim of identifying meaning units that express self-contained meanings from a psychological perspective. The task is to articulate the central meanings that characterise the research participant's account. 
- Step 3: Reflect on and express the psychological insight contained in all the meaning units more directly as transformed meaning units. The transformed meaning units articulate explicitly the implicit psychological aspects of each meaning unit identified in Step 2.

- Step 4: Synthesise and integrate the insights contained in the transformed meaning units into consistent and systematic narrative descriptions of the psychological structure of the research participant's experiences.

Direct quotes from the interviews and documentary materials are presented in the Findings section to illustrate the various lived experiences. Pseudonyms have been used for the research participants to protect their anonymity. The interview quotes have been reported in translation where the interview was conducted in Afrikaans.

\section{ETHICAL CONSIDERATIONS}

Ethical clearance was granted by the Faculty Academic Ethics Committee of the Rand Afrikaans University ${ }^{2}$ and the Ethics Committee of Technikon Pretoria. ${ }^{3}$ Generally accepted ethical principles were followed during the recruitment of participants, data collection and data analysis (MRC 2002; Munhall 1994:151-157). No monetary incentives were offered to potential research participants. An information leaflet that outlined the study's aim, duration, potential benefits and potential emotional discomfort was provided to each potential research participant. The information leaflets assured them of voluntary participation, freedom to withdraw without penalty, anonymity and confidentiality. We were sensitive to the fact that having to recall emotions, thoughts and actions during the study could, for some participants, be the beginning of a renewed personal trauma. As such, the principle that the therapeutic imperative takes precedence over the research imperative was followed. The research participants had free access to the counselling services of a resident psychologist.

\section{TRUSTWORTHINESS}

The two most important credibility strategies that were employed to verify the trustworthiness of the research were member checking and peer review. All the research participants were provided with a copy of their transcribed interview/s and a full written report of the data analysis report. They were then requested to verify the accuracy and credibility of the documents (Krefting 1991:219; Mayan 2001:28). Furthermore, an independent counselling psychologist with extensive experience in phenomenological research conducted an external audit and peer review of the research process and analysed data (Smith 2003:234-244)

\section{FINDINGS AND DISCUSSION}

\section{Contextualisation of the research participants}

In order to increase the presence and voice of the research participants in the article, the following basic information is relevant:

- Shirley was an 18-year-old student at the time of the interview. Her older brother, an engineering student, had completed suicide three years earlier in his room by hanging. They had a close friendship relationship.

- Ilze was a 21-year-old student at the time of the interview. Her mother had suffered from a chronic gastrointestinal disorder that led to an addiction to analgesics. She had completed suicide two years earlier by taking an overdose of pills.

\footnotetext{
2.This university was integrated into the University of Johannesburg on 01 January 2005

3. This tertiary institution was integrated into the Tshwane University of Technology on 01 January 2004
}

- Maria was a 19-year-old student at the time of the interview. Her niece of the same age had completed suicide 13 months earlier in her parental home by means of a fatal wound from her father's firearm. She and Maria had a close friendship relationship.

- Megan was a 22-year-old student at the time of the interview. Her male friend had completed suicide five years earlier by taking an overdose of pills. He had been a year younger than Megan. They had known each other for only 15 months, but had a close friendship relationship.

- Annie was an 18-year-old Grade 12 learner at the time of the interview. A fellow learner had completed suicide at school four years earlier by means of a fatal gunshot. Since then, a close female friend had completed suicide in the same manner, while a niece had attempted suicide in her room by taking an overdose of pills only a few minutes before she was discovered by Annie.

\section{Lived experiences}

Nine specific lived experiences that seemed to worsen in the weeks and months after a significant other's completed suicide emerged from the data analysis. These were, (1) guilt, (2) selfblame, (3) blaming others or God, (4) anger, (5) loss or restriction of 'self', (6) depression, (7) suboptimal behavioural coping patterns, (8) changes in relationship dynamics and (9) suicidality.

\section{Guilt}

Guilt is a feeling of responsibility or remorse for a real or imagined offence or crime - 'acts of commission'. Owing to the questions that it raises regarding blame and punishment, feelings of guilt are often accompanied by remorse, negative self-evaluation or feelings that one should atone in some way (Du Plessis 2003:23; Rosenfeld \& Prupas 1984:19-20). This multifaceted emotion is one of the most difficult with which suicide survivors need to cope. Guilt-ridden survivors often fail to recognise that guilt is actually a false accusation against themselves (Jackson 2003:16). Earlier studies suggested that suicide survivors' guilt occurs more frequently, with greater intensity, and for longer periods of time than for other forms of death (Henley 1984:55). However, a recent review study by Sveen and Walby (2008:24) found no clear evidence to support this notion. They only found indications of a weak tendency toward relatively higher levels of guilt for suicide survivors in the first 18 months.

In our study, some of the research participants reported a troubled relationship between themselves and the suicide victim prior to the suicide as an important aspect of their guilt feelings. In some cases the survivors directly accepted responsibility for the relationship issues that seemingly lead to the suicide:

Ilze: 'If I could change anything ... I wouldn't have sided with my dad as much as I did ... when they were considering a divorce ... I can't forgive myself ... because I now know, after everything that happened ... [my mom] needed me and I pushed her away ... I just wasn't there ... I feel that I could have changed it ...'

A pattern of guilt feelings often follows the loss of relationships that were ambivalent and/or troubled. Such a pattern becomes a destructive process in which one is worthy and deserving of punishment (Fourie 2003:3). This guilt is often based in the imperfectness of human relationships. These suicide survivors tend to measure themselves against 'perfect' relationship standards while ignoring the imperfect nature of relationships or failing to acknowledge their positive contributions to it (Rando 1993:481).

Feelings of having done something wrong are often based in social rules, religious beliefs or the perception that a personal standard has been violated. Such feelings of guilt result in the expectancy that punishment and a need for atonement has to follow (Du Plessis 2003; Helen 2002:14). In Maria's words:

'That was punishment; it was too much for me ... at first I thought [my cousin] did it ... because she didn't even contact me to tell me anything ... I felt I was not always in contact with her.' 
The intensity of survivors' guilt feelings is often evident in the experience that it seems to persist and even increase over time. Such persistent guilt places an emotional burden on suicide survivors that may immobilise their personal growth (McMenamy et al. 2008:379; Sudak et al. 2008:137). The following extract from Ilze's interview exemplifies this experience:

'I will always have this guilt feeling that I have now ... some days it gets to me and I feel ... it is my fault ... then some other days I feel better ... it is like a roller coaster ...

The unfinished nature of guilt feelings often interferes with survivors' ability to accept and adapt to a changed life; it keeps them chained to the past (Du Plessis 2003:3; Rando 1993:482483). Part of what is so painful about survivors' guilt feelings is that they cannot confirm with the victim whether the guilt is justified or not; they can only speculate and continue to feel guilty (Lukas \& Seiden 1987:37; Rando 1993:169, 479). In this process, the survivors fail to acknowledge that guilt should only be apportioned where one has clearly intended malicious actions, or at least recklessly disregarded their consequences (McGraw 1999:64-65).

\section{Self-blame: 'If only I had ...'}

Self-blame is a common experience among suicide survivors. It refers to the sense that if only one had done more, loved more, listened more or been around more, then things might have turned out differently. Self-blame is closely related to guilt feelings. Guilt is primarily an emotional pattern based on actions that somehow contributed to the suicide ('acts of commission') while self-blame is primarily a cognitive pattern based on the absence of efforts that seemingly could have prevented the suicide ('acts of omission') (Cerel et al. 2008:39; Jackson 2003:1620).

One self-blame experience among the research participants was 'if only I had given the victim a reason to continue with life'

Maria: 'I was not always in contact with [my cousin] ... I feel I should have done something in a way ... if maybe I called her ... the day before she thought about everything ... it could have changed everything.'

Another distinct self-blame experience among the survivors in our study was 'if only I had acted on the cues of the imminent suicide':

Annie: '[My friend $]$ shot herself through the heart ... two evenings before that ... she said 'You will never again see me cry'... [those were the] words she gave us ... I blamed myself ... why didn't I just listen to her ... she made it so clear ... why was I so stupid?'

Previous research indicates that suicide survivors report a greater sense of responsibility for a significant other's suicide when compared with natural death survivor groups (Bailley, Kral \& Dunham 1999:268). In retrospect, they experience that the warning signals of suicidal intent were obvious and explicit. When they know the devastating outcome of such warning signals, this perfect hindsight tends to highlight their perceived failure to anticipate and prevent the suicide (Calhoun \& Allen 1991:99; Cerel et al. 2008:39).

\section{Blaming others or God}

Blame refers to the attribution of personal responsibility, coupled with disapproval (Dunn \& Morrish-Vidners 1987-1988:184). The frequent ambiguity of causes and/or the specific context around a suicide seems to increase the need within the social network to assign blame (Cerel et al. 2008:39). The act of blaming others or God is one way to release the victim of blame and responsibility for the suicide (Jackson 2003:21).

Survivors sometimes blame other significant persons for their perceived negative interpersonal relationship with the victim that seemingly contributed to the suicide events:
Maria: '[My cousin's] parents ... I am blaming them because they are the ones who made sure ... she was always restricted ... they didn't want her to do anything ...'

Furthermore, others are occasionally blamed for perceived acts of omission or neglect that, at least in the mind of the survivor, could have prevented the suicide events:

Maria: 'I blame her parents for having a gun in the house but... not keeping it in a safe place ... you should place it where your kids ... they should not know the codes to that safe ... 'cause if the gun was not there ... what could she have done? ... [S] he could have tried other means and maybe ... she could just fail to kill herself.'

A review study (Sveen \& Walby 2008:22) found that suicide survivors experience significantly higher levels of blaming than survivors of other modes of death. Blaming is used by survivors to regain a sense of control and structure. It allows the displacement of anger and guilt from the victim and oneself onto someone else (Dunn \& Morrish-Vidners 1987-1988:185). It serves to protect the survivor from emotions and thoughts that are too painful to deal with. However, while blaming can initially restore a sense of order, persistent blaming can negatively affect free communication between survivors (Cere et al. 2008:39; Hauser 1987:66). Ultimately, it may result in deep frustrations that complicate the healing process.

Many suicide survivors report a loss of faith and/or anger at God in the aftermath of a suicide (Hamilton \& Masecar 2001:48). Survivors sometimes blame God for allowing the victim to experience the negative emotions and circumstances that led to the completed suicide (Rubey \& Clark 1987:155). In Annie's words:

'They say that God lifts you up when you need Him, but I argued with Him in my prayers because I asked "Why weren't You there?" ... I blamed God, I was angry with God ... "Why must people go through so much pain?" ... "Why must everything go wrong?" ... I always thought He was a God of love ...'

Sometimes God is blamed for not preventing the suicide:

Maria: 'Sometimes I would blame God ... "How can you let this happen?" ... I mean He could have stopped it in a second if He wanted to, but then He didn't.

One outcome of survivors' tendency to blame God is to question and/or reject their own religious beliefs (Hamilton \& Masecar 2001:48; Kinsella, Greeff \& Poggenpoel 1993:46). This is evident in the following quote:

Annie: 'I even questioned God and my Christian beliefs ... it felt as if I had lost contact with God ... because I blamed God ... that's why I wanted to completely get rid of God ... I viewed Christian beliefs as worthless ...'

Survivors frequently feel angry and disillusioned at God for seemingly allowing the suicide to occur. The result is numerous questions regarding faith and the role of religion in one's life. The ambivalence between believing and protesting against God is indicative of a cognitive uncertainty to make sense of life without the victim (Matthews \& Marwit 2006:92-96). When the loss cannot be integrated into existing religious beliefs and practices, it may result in a review, reformulation or rejection of those beliefs to accommodate the loss (Nolte 2005; Opperman \& Novello 2006:384).

\section{Anger}

The emotional legacy of suicide is often a combination of blame, guilt, anger and stigma (Ratnarajah \& Schofield 2007:79). Suicide survivors sometimes focus their anger on the victims' seemingly deliberate abandonment or avoidance of an interpersonal context where problems could have been sorted out. Instead of dealing with the problems within this context, the victims apparently rather chose to betray trusted relationships that were not allowed an opportunity to help (Jackson 2003:21; Silverman, Range \& Overholser 1994-1995:49). This is evident in the following extract: 
Shirley: '[My brother and I] were very close ... I would have thought if he had a problem, he would have told me ... I didn't understand when he did something alone and I didn't even know it ... that's why I think I resented him ... if he could talk to me about anything else, why couldn't he talk to me about this?'

In other cases, the survivors' anger is focused on the victim's abandonment/rejection behaviour (Alexander 1991:285; Helen 2002:76). One of the participants experienced that the victim had explicitly rejected her attempts to repair a broken relationship, prior to the suicide events:

Ilze: 'Mom and I had a stupid argument. She doesn't return home that evening. I phone her. "You don't need me" were her words. She shouldn't have said those words ... everyone argues one time or another ... her last words weren't right ... if she knew that she was going to do it, why did she also want to destroy me?'

Suicide survivors' primary loss in a completed suicide context is the actual death of the significant other person. Other losses include profound rejection and abandonment by the significant other who preferred death above their relationship, as well as disillusionment in the personhood of the suicide victim (Silverman et al. 1994-1995:49). The victim's choice to die often elicits cognitive ruminations on how little the survivor apparently must have meant to the victim. In addition, the suicide sometimes leaves survivors to deal with memories of a last, angry interpersonal exchange (Wertheimer 1991:44). Sveen and Walby's review study $(2008: 15,24)$ found that suicide survivors consistently experience a greater sense of rejection than survivors of other modes of death. It is no wonder then that survivors interpret and perceive the suicide as an intentional punishment and deliberate rejection of their personhood.

Another aspect that evokes anger towards suicide victims is the emotional hurt that they leave behind for the survivors to deal with. The following extract is illustrative:

Shirley: 'Right now I am very angry ... because [my brother] put me through so much ... I'm not strong ... and he knew that ... and he still did what he did ... there was no proper goodbye ... we just found him hanging ... how could you put people you claim you love through so much pain?'

The emotional hurt and unfinished relationship business that survivors often face in the aftermath of a completed suicide are partially the result of the victim's inherent betrayal and abandonment (Hamilton \& Masecar 2001:47). The survivors had no choice in the act that left the loved one dead, but it is they who have to cope with the bewildering array of emotions and questions (Jackson 2003:2; Wertheimer 1991:171-172).

\section{Loss or restriction of 'self'}

The death of a significant other often leaves survivors with a sense of loss/restriction of their past and future. It is not only as a result of the death of the other person, but also the loss of a part of the survivor's sense of 'self' (Carter 1989:356; Matthews \& Marwit 2006:90-91). One significant loss of 'self' suffered by suicide survivors is the suicide victims' socio-emotional support, care and friendship:

Shirley: 'A part of me died when my brother died ... a huge part of me ... I looked after him ... he's my big brother ... he [came to] pick me up after school ... it's [been] three years now; you [would] expect it [to be] better now ... but it seems as if it is getting worse because you think if he was here now, he'll be doing this or we'll be doing that ...'

Erikson's psychosocial theory of human development describes the principal task of the young adult as intimacy versus isolation (Hook 2009:302). The loss of a close friend during this developmental stage, which follows on adolescence, may lead to feelings of depression, abandonment and despair (Feigelman \& Gorman 2008:191; Webb 1986:472). Thus, the primary loss of a significant other may be compounded by a number of symbolic losses, such as reciprocal intimacy. This, in turn, may result in a crisis of meaning in which the survivor has to make sense of the death and find meaning in continuing life without the victim (Opperman \& Novello 2006:377).

A second loss of 'self' that survivors experience is the loss and/ or restriction of significant personal emotions, thoughts and selfregard. This experience can be thought of as an amputation that leaves survivors feeling as though a significant part of them is missing (Wertheimer 1991:103):

Megan: (when talking about a collage picture of a naked girl) '... she doesn't have any clothes on or have anything with her ... that's how I felt ... everything was taken from me ... I was absolutely naked ... my emotions were gone, my thoughts, my material worth, everything ...'

A third, important loss of 'self' is associated with a sense of restricted access to a meaningful future. Such an indifferent and fatalistic experience may originate from the survivors' sense of disillusionment in life. This often adversely affects relational commitments to significant others and to life events (Dunn \& Morrish-Vidners 1987-1988:205; Nicholls 2007:91-92):

Shirley: 'You don't care anymore ... I don't care about half the things that happen ... I have this "don't care" attitude now; I don't care ...'

A last, salient loss of 'self' is based in new role expectations from changed social and/or family interactions. These expectations are often experienced as something that restricts and overwhelms their personhood:

Shirley: 'Everybody just expects me to be this superhuman who can listen to [them] and not have problems of [my] own, and tell you what to do and what not to do ... I feel it's too much pressure for me at times and I cannot handle it ... I'm expected to know how to deal with it, because [now] I'm the big sister; I'm the star of the family ... I think they are expecting way too much from me ... and I cannot ... now I feel like I have chains ...'

The interactions we have with significant others play an integral role in our sense of 'self'. Thus, physical and symbolic losses associated with the death of a significant other can pose a substantial existential threat (Ratnarajah \& Schofield 2007:88). This may explain why so much of the suicide aftermath crises for survivors originate in the loss of so much of the 'self'. A part of the survivor invariably dies with the victim (Opperman \& Novello 2006:383). When the suicide victim is a sibling of an adolescent survivor, the one left behind often becomes the focus of the family's attention, expectations and unrealistic demands. All their expectations are now directed towards the remaining child; the idealised characteristics and unrealised potential of the victim is redirected towards the survivor (Helen 2002:67-68; Rosenfeld \& Prupas 1984:81).

\section{Depression}

Depression is a salient, experiential response to a suicidal death (Feigelman \& Gorman 2008:191; Sudak et al. 2008:137). In this article, the phenomenon of 'depression' does not imply a clinical diagnosis, but rather refers to the research participants' phenomenological lived experience. The research participants associated a number of physiological, somatic, cognitive and existential responses with their experience of depression:

- bouts of crying; Ilze: (diary entry) 'Today I am feeling very depro [sic]; my friend cries as much as I do.'

- weight gain; Ilze: 'I am falling into a deep depression ... my boyfriend tells me that I have gained weight ... I know that I have gained approximately eight kilograms ...

- decreased motivation to engage in meaningful activities; Ilze: 'In the first two months after my mom's suicide I didn't care about anything ... I neglected my studies ... I did nothing ... I neglected my boyfriend ...'

- perception that everything is getting worse, where small problems seem like big challenges; Ilze: '... after 2 years ... things didn't get better, everything got worse ... every small thing becomes a mountain ... you don't want to go over the mountain because there is another one, and another one.' 
- interpreting own life as a failure and not having an impact on others' lives; Megan: 'In my Grade 12 year ... I just couldn't see above me ... it was too dark for me ... I increasingly felt like a failure because I failed at school and my friends... I really felt that I was a failure ...'

A number of studies among adolescents and university students found that depression was the most common emotional response to the suicide of a significant other. It included feelings of apathy, fatigue, emptiness, despair, crying, sadness and exhaustion (Dyregrov \& Dyregrov 2005:715; Feigelman \& Gorman 2008:191). Depression plays an important role in survivors' tendencies to lose weight or overeat, as well in their tendency to not form new relationships due to low self-esteem (Brent et al. 1993:252; Lukas \& Seiden 1987:39; Seeber 2002:34). However, it is important to note that the review study by Sveen and Walby (2008:23) found very few significant differences in the levels of depression between suicide survivor groups and other survivor groups.

\section{Suboptimal behavioural coping patterns}

Bereaved individuals' lack of optimal coping skills can hamper their exploration of appropriate behavioural coping patterns for a life without a significant other (Rando 1993:441). In the case of suicide survivors, the implicit motivation to engage in suboptimal behavioural coping patterns in the aftermath of a completed suicide is an attempt to escape or avoid direct engagement with intense emotions and thoughts. Some of the participants in our study resorted to two of the more common coping patterns, namely cigarette smoking and alcohol misuse. Cigarette smoking is frequently used to deal with life stressors:

Shirley: 'I started smoking, I just want something [to] take that away ... because I'm thinking 'If I can not take [it], I'll smoke [it] away', it doesn't help, but just smoke it away.'

Alcohol misuse is sometimes engaged in as a way to deal with social isolation and peer rejection in the aftermath of suicide events:

Megan: 'Back at school ... my friends questioned the relationship I had with [my friend] ... it was a big, negative thing ... then I started drinking ... so heavily that I was very drunk ... as in, I didn't know what I [was] doing ... I thought that I was becoming cool in doing what my friends did.

Alcohol misuse can also play a role in attempts to forget or deny the impact of the suicide events:

Megan: 'I started drinking and never dealt with or accepted [my friend's suicide] ... only going on with life without wanting to look back [at] it ... I used alcohol as a crutch to carry me through ...'

A number of studies have found marked increases in alcohol consumption and tobacco use among bereaved individuals (Watson \& Lee 1993:37). The misuse of alcohol and other substances is regarded as a risk and predictive factor for poor progress in the mourning process. It is viewed as a source of temporary comfort, avoidance or escape from emotional pain (Seeber 2002:38). The 'feeling good' effects provide a false sense of mastery and control over the mourning process.

\section{Changes in relationship dynamics}

The death of a significant other almost always results in altered relationship patterns and interpersonal dynamics due to its role in an individual's sense of meaning and purpose in life (Ratnarajah \& Schofield 2008:625-627; Ulmer, Range \& Smith 1991:280). The research participants in our study experienced three significant changes in their relationship dynamics: close relationships became superficial or troubled, avoidance and distancing from close relationships and concealment of suicideas-reason-for-death in social interactions.

Close relationships with significant others may become superficial in the aftermath of a significant other's suicide:

Ilze: '[My dad and I] were very close, extremely close [before my mom's suicide] ... I think that I knew everything about my dad, he knew everything about me ... but now ... we are not as close as we were.'

In other cases, the survivors experienced increased conflict in close relationships:

Ilze: 'My sister ... we started to fight ... she couldn't understand what was happening ... my boyfriend and I fought a lot ...'

Many relationships with significant others, including those with family members and friends, may become increasingly superficial and troubled in the aftermath of a completed suicide. Some of the important factors that contribute to this are mutual blaming, precipitation of problematic relational issues, and feelings of guilt (Dunn \& Morrish-Vidners 1987-1988:190; Dyregrov \& Dyregrov 2005:721-722). In the case of a parent's suicide, the relationship between children and the surviving parent can become very difficult, with the surviving parent unable to maintain a deep relational commitment and support for the bereaved children (Ratnarajah \& Schofield 2008:623).

Survivors sometimes intentionally choose to avoid and/or distance themselves from close relationships in the aftermath of a completed suicide. The suicide is experienced as the ultimate rejection (Cvinar 2005:17; Sveen \& Walby 2008:15, 24):

Shirley: 'I push people away ... I don't want anyone close to me ... because if they say they love you, like my brother did, they just leave you ... if people like that can put you through so much pain, what can stop a stranger? ... I find it very difficult to have somebody very close to me ... so I keep by myself.'

The suicide victim's desertion of a significant relationship is interpreted by suicide survivors as an indication that their relationship was somehow not providing enough reason to choose life above death, or at least not providing a sufficiently safe and trusted context. As a result, survivors can't find any reason why such a betrayal could not come from anyone else. This loss brings feelings of insecurity that deeply impacts on the survivor's sense of trust in relationships (Helen 2002:68; Wertheimer 1991:174). Thus, to protect them from being rejected or abandoned again, the survivors now do the rejecting (Lukas \& Seiden 1987:94; Ratnarajah \& Schofield 2008:625).

Some suicide survivors intentionally conceal the fact of suicideas-the-reason-for-death in most social interactions, with the possible exception of very close significant persons:

Ilze: 'No one knows that my mom committed suicide ... for me it is a suicide, but nobody else knows ... my friends know that my mom died of cancer ... I don't want them to know ... my dad's family knows ... I won't tell anybody else ... for me it is my own privacy ... I don't want anyone to know it.'

Over many centuries, society at large has been intensely apprehensive of suicide. Today the subject of suicide remains largely a social taboo (Cvinar 2005:14-15; Schlebusch 2005:1). The degree to which suicide survivors experience social discomfort is evident in their concealment of the cause of death. A number of studies have found that suicide survivors, when compared to other natural death survivor groups, report more telling others that the cause of death was something other than suicide (Sveen \& Walby $2008: 15$, 24). This may be an attempt to avoid public scrutiny and stigmatisation; if the death can be described as an accident or due to natural causes, then no one is to blame and no one needs to feel guilty. In this regard, stigmatisation refers to the phenomenon of shame or disgrace that potentially detracts from the character or reputation of a person, coupled with an internalisation of negative attitudes towards the self (Rohleder \& Gibson 2006:26). Survivors are often acutely aware that disclosure of suicide-as-reason-for-death poses significant social risks because the social reactions towards stigmatised individuals are often associated with restricted social support, increased social isolation and avoidance (Cvinar 2005:19; Range \& Calhoun 1990:317; Ratnarajah \& Schofield 2008:625). 


\section{Suicidality}

Adolescent suicide survivors have a higher tendency than other survivor groups to engage in suicidal thinking and suicide attempts in the first year following a significant other's suicide (Feigelman \& Gorman 2008:191). Ilze, for example, admits, 'I have thought about suicide a million times.'

It seems that survivors' exposure to suicide cases brings an acute awareness of suicide as a coping option for life's problems:

Megan: 'One of my motivations [to attempt suicide] was that if he could do it, why can't I?... [H]e could get out of his situation, why can't I?'

Suicide thoughts are not uncommon among suicide survivors during the early months of bereavement (Feigelman \& Gorman 2008:189-191; Kinsella et al. 1993:46). This may be as a result of the significant other's death that makes the very idea of suicide more real in the survivor's life. It reframes the previously unthinkable idea of suicide into a viable option in the event of great stress, difficulties or crises (Dunn \& Morrish-Vidners 1987-1988:209).

A longing to be reunited with the victim is another experience that is closely related to survivors' suicide thoughts in the aftermath of a significant other's suicide. Some survivors believe or hope that their own death will bring an opportunity to question the victim about the reason/s for the completed suicide:

Shirley: 'Sometimes ... I was thinking "If I were to die, then maybe I would see him ... and I'd ask him" ... 'cause right now, I would die just to know "Why [did] you [have] to?"'

The fragility of some adolescents' ideas related to the finality and irreversibility of death can result in the idiosyncratic belief that a reunion with the victim may be possible. The wish to rejoin the victim is often based in a close identification with the deceased person (Balk 1983:154-155; Joiner 2005:165-170).

The experiential contexts within which suicide attempts occur in the aftermath of a significant other's suicide are complex and varied. The research participants in our study reported a number of experiences that had contributed to their suicide attempts. The first was a sense of pervasive hopelessness. Hopelessness represents an important link between depression, suicide thoughts and suicide attempts (Joiner 2005:38-39; Stillion \& McDowell 1996:58-60):

Annie: 'There are times that I still remember that hopelessness ...

it felt as if you can just disappear and it would be better... I hate it

... it is probably depression ...'

Another factor in survivors' suicide attempts was their sense of failure in life:

Megan: '... about a year after [my friend's] suicide, I tried to commit suicide ... it was in my matric year ... I just couldn't see above me ... it was too dark for me ... I felt increasingly like a failure because I failed at school and my friends... I really felt that I was a failure ... it wouldn't have mattered if I was there or not ...'

A last factor that significantly contributes to adolescent survivors' suicide attempts is their sense of loneliness, social isolation and a lack of appropriate social support (Joiner 2005:122-124; Stillion \& McDowell 1996:113). However, it is important to note once again that the study by Sveen and Walby (2008:24) found little support that suicide survivors experience loneliness more often than other bereaved groups:

Annie: 'It felt to me as if no one noticed my experiences, as if I was alone ... I am the only one who is experiencing it and nobody will understand what I felt ... it was as if I was completely alone ... that loneliness was the worst ... I just couldn't reach out to others ... I wished someone could reach out to me ... all I wanted to do in that situation was to be able to talk to someone ...'

\section{LIMITATIONS AND RECOMMENDATIONS}

The study has two important limitations. Firstly, it exclusively focused on the lived experiences of female participants. Secondly, the use of collages as narrative-facilitators during the collection of phenomenological data only represents a snapshot of the participants' lived experiences at the specific time of its creation. This limits our current understanding of the dynamic nature of changes and longitudinal progression in the survivors' lived experiences.

As such, we want to recommend that three research themes urgently be addressed. These are: firstly, an exploration of the lived experiences of adolescent male suicide survivors, secondly, longitudinal studies regarding the course of suicide survivor bereavement and grief patterns and, lastly, narrative research that focuses on the current use of suicidology concepts and constructs that often carry messages about crime ('committing'), murder ('killing oneself') and life task ('successful suicide' and 'failed suicide attempt').

\section{CONCLUSION}

The main focus our study was to explore the lived experiences of late-adolescent suicide survivors, particularly those experiences that seemed to worsen in the weeks and months after the event. Much of what is currently known about suicide survivor responses and outcomes in the aftermath of a significant other's completed suicide rests on the results of quantitative studies. However, an important strength of qualitative studies is its capacity to elicit rich information from potentially hidden or hard-to-reach groups (Ratnarajah \& Schofield 2008:628). From a phenomenological perspective, our study contributes to a deeper understanding of late-adolescent suicide survivors' lived experiences. The results indicated that the completed suicide of a significant other triggered a number of negative experiences, one of which was aptly described by a participant as '[a] part of me died'. The results included the following salient experiences: guilt, self-blame, blaming others or God, anger, loss or restriction of 'self', depression, suboptimal behavioural coping patterns, changes in relationship dynamics, and suicidality. These experiences seemed, at times, intense enough to overwhelm the suicide survivors emotionally, to potentially prolong the grieving and healing processes and to place them at increased psychological and physical risk. However, it is important to keep in mind that these experiences represent natural expressions of painful feelings and thoughts. Suicidality is a natural response to the suicide of a significant other, anger is natural, some guilt is natural, loss of 'self' is natural, and so is depression (Lukas \& Seiden 1987:136).

Ultimately, survivors may experience the onset of healing when they acknowledge these lived experiences. Gradually they may then move towards healthy adjustment to 'normal' life and integration into the changed world around them. However, sometimes suicide survivors may become so stuck, their emotions so distanced, their guilt so great and their anger so intense, that they find it impossible to move forward on their own. In these cases they may find professional interventions very helpful (Barrett \& Scott 1990:2; Dunn \& Morrish-Vidners 1987-1988:175-176; Lukas \& Seiden 1987:136-137).

Most, if not all, survivors eventually come to accept that the suicide events can never be undone or made less tragic. They learn to go on without the deceased, while at the same time the suicide victim is not forgotten altogether. Also, they learn to adjust to a new relationship with themselves (i.e. revising their assumptive world and establishing a new personal identity) and the external world (i.e. family roles and social skills) (Lukas \& Seiden 1987:144; Rando 1993:40-41). 
Mental health professionals, counsellors, lecturers, teachers, ministers of religion, parents, siblings and friends can use the results of this study to effectively support adolescent suicide survivors in the midst of their mourning. A rich comprehension of survivor experiences can assist and empower mental health professionals to provide sensitive psychoeducation, effective postvention interventions and informed support to suicide survivors (Theron \& Gilgun 2009:227)

\section{ACKNOWLEDGEMENTS}

The Canadian Commonwealth Scholarship Program is acknowledged for funding the first author's doctoral residency at the International Institute for Qualitative Methodology, University of Alberta, Edmonton, Canada. Also, the valuable inputs and comments of two anonymous reviewers are acknowledged.

\section{REFERENCES}

AFSP Workshop, 2003, AFSP releases report on survivors of suicide research workshop, viewed 14 June 2005, from http://www. afsp.org/survivor/sosworkshop903.htm

Alexander, V., 1991, 'Grief after suicide: Giving voice to the loss', Journal of Geriatric Psychiatry 24, 277-291.

Bailley, S.E., Kral, M.J. \& Dunham, K., 1999, 'Survivors of suicide do grieve differently: Empirical support for a common sense proposition', Suicide and Life-Threatening Behavior 29(3), 256-271

Balk, D., 1983, 'Adolescents' grief reactions and self-concept perceptions following sibling death: A study of 33 teenagers', Journal of Youth and Adolescence 12(2), 137-161.

Barrett, T.W. \& Scott, T.B., 1990, 'Suicide bereavement and recovery patterns compared with nonsuicide bereavement patterns', Suicide and Life-Threatening Behavior 20(1), 1-15.

Bolton, I.M., 1987, 'Our son Mitch', in E.J. Dunne, J.L. McIntosh \& K. Dunne-Maxim (eds.), Suicide and its aftermath: Understanding and counseling the survivors, pp. 85-94, Norton, New York.

Brent, D.A., Perper, J., Moritz, G., Liotus, L., Schweers, J., Roth C. et al., 1993, 'Psychiatric impact of the loss of an adolescent sibling to suicide', Journal of Affective Disorders 28, 249-256.

Calhoun, L.G. \& Allen, B.G., 1991, 'Social reactions to the survivor of a suicide in the family: A review of the literature', Omega 23(2), 95-107.

Carter, S., 1989, 'Themes of grief', Nursing Research 38(6), 354-358.

Cerel, J., Jordan, J.R. \& Duberstein, P., 2008, 'The impact of suicide on the family', The Journal of Crisis Intervention and Suicide Prevention 29, 38-44.

Creswell, J.W., 1998, Qualitative inquiry and research design: Choosing among five traditions, Sage, Thousand Oaks.

Cvinar, J.G., 2005, 'Do suicide survivors suffer social stigma: A review of the literature', Perspectives in Psychiatric Care 41(1), $14-21$

Dunn, R.G. \& Morrish-Vidners, D., 1987-1988, 'The psychological and social experience of suicide survivors', Omega 18(3), 175-215.

Du Plessis, J., 2003, 'Guilt: A stumbling block on the road of life', unpublished notes for a meeting at the University of South Africa, 24 April.

Dyregrov, K. \& Dyregrov, A., 2005, 'Siblings after suicide - "The forgotten bereaved"', Suicide and Life-Threatening Behavior 35(6), 714-724.

Feigelman, B. \& Feigelman W., 2008, 'Surviving after suicide loss: The healing potential of suicide survivor support groups', Illness, Crisis and Loss 16(4), 285-304.

Feigelman, W. \& Gorman, B.S., 2008, 'Assessing the effects of peer suicide on youth suicide', Suicide and Life-Threatening Behavior 38(2), 181-194.
Fourie, K.D., 2003, 'Working with guilt', Hypnos SA 1(August), 3.

Giorgi, A., 1985, 'Sketch of a psychological phenomenological method', in A. Giorgi (ed.), Phenomenology and psychological research, pp. 8-22, Duquesne University Press, Pittsburgh.

Giorgi, A., 1989, 'One type of analysis of descriptive data: Procedures involved in following a scientific phenomenological method', Methods 1(3), 39-61.

Giorgi, A., 1997, 'The theory, practice, and evaluation of the phenomenological method as a qualitative research procedure', Journal of Phenomenological Psychology 28(2), 235-260.

Hamilton, L. \& Masecar, D., 2001, Counselling the bereaved: Caregiver handbook, rev. edn., Suicide Prevention Training Programs, Calgary.

Harris, J., 2002, 'The correspondence method as a data-gathering technique in qualitative enquiry', International Journal of Qualitative Methods 1(4), Article 1, viewed 18 December 2002, from http:/ / www.ualberta.ca/ ijqm/

Hauser, M.J., 1987, 'Special aspects of grief after a suicide', in E.J. Dunne, J.L. McIntosh \& K. Dunne-Maxim (eds.), Suicide and its aftermath: Understanding and counseling the survivors, pp. 57-70, Norton, New York.

Helen, M., 2002, Coping with suicide, Sheldon Press, London.

Henley, S.H.A., 1984, 'Bereavement following suicide: A review of the literature', Current Psychological Research and Reviews $3(2), 53-61$.

Hoffmann, W.A., 2002, 'The incidence of traumatic events and trauma-associated symptoms/experiences amongst tertiary students', South African Journal of Psychology 32(4), 48-53.

Hoffmann, W.A., 2004, "Being an adolescent suicide survivor" - A collage-facilitated phenomenological approach', DEd thesis, Department of Educational Psychology, Faculty of Education and Nursing, Rand Afrikaans University.

Hoffmann, W.A., 2007, 'Disorganisasiebelewenisse van vroulike laat-adolessente selfmoordagtergeblewenes [Disorganisation experiences of female late adolescent suicide survivors]', Tydskrif vir Geesteswetenskappe 47(3), 431-444.

Hook, D., 2009, 'Erikson's psychosocial stages of development', in J. Watts, K. Cockcroft \& N. Duncan (eds.), Developmental psychology, 2nd edn., pp. 283-311, UCT Press, Cape Town.

Jackson, J., 2003, A handbook for survivors of suicide, American Association of Suicidology, Washington.

Joiner, T., 2005, Why people die by suicide, Harvard University Press, Cambridge.

Kinsella, J., Greeff, M. \& Poggenpoel, M., 1993, 'Belewenis van persone na aan selfmoord slagoffers [Experiences of people close to suicide victims]', Curationis 16(4), 43-49.

Krefting, L., 1991, 'Rigor in qualitative research: The assessment of trustworthiness', The American Journal of Occupational Therapy 45(3), 214-222.

Kruger, D., 1988, An introduction to phenomenological psychology, 2nd rev. edn., Juta, Cape Town.

Laverty, S.M., 2003, 'Hermeneutic phenomenology and phenomenology: A comparison of historical and methodological considerations', International Journal of Qualitative Methods, viewed 3 October 2003, from http:// www.ualberta.ca/ iiqm/backissues/2_3final/pdf/laverty. pdf

Lukas, C. \& Seiden, H.M., 1987, Silent grief: Living in the wake of suicide, Papermac, London.

Matthews, L.T. \& Marwit, S.J., 2006, 'Meaning reconstruction in the context of religious coping: Rebuilding the shattered assumptive world', Omega: The Journal of Death and Dying 53(1\&2), 87-104.

Mayan, M.J., 2001, An introduction to qualitative methods: A training module for students and professionals, International Institute for Qualitative Methodology, Edmonton.

McGraw, P.C., 1999, Life strategies - Doing what works, doing what matters, Vermillion, London.

McIntosh, J.L., 1996, 'Survivors of suicide: A comprehensive bibliography update, 1986-1995', Omega: The Journal of Death and Dying 33(2), 147-175.

McMenamy, J.M., Jordan, J.R. \& Mitchell, A.M., 2008, 'What do suicide survivors tell us they need? Results of a pilot study', Suicide and Life-Threatening Behavior 38(4), 375-389. 
Morse, J.M., 1995, 'The significance of saturation (Editorial)', Qualitative Health Research 5(2), 147-149.

Morse, J.M., 2000, 'Determining sample size (Editorial)', Qualitative Health Research 10(1), 3-5.

MRC, 2002, Guidelines on ethics for medical research: General principles, 4th edn., South African Medical Research Council, Tygerberg, Cape Town.

Munhall, P.L., 1994, Revisioning phenomenology: Nursing and health science research, National League for Nursing Press, New York.

Nicholls, V., 2007, 'Loss and its truths: Spirituality, loss, and mental health', Illness, Crisis and Loss 15(2), 89-98.

Nolte, C., 2005, Wanneer God in my pyn verdwyn [When God disappears in my pain], Lux Verbi, Wellington.

Opperman, B. \& Novello, A., 2006, 'The generation of hypotheses with regard to the influence of context on complicated grief', South African Journal of Psychology 36(2), 374-390.

Radley, A. \& Taylor, D., 2003, 'Images of recovery: A photoelicitation study on the hospital ward', Qualitative Health Research 13(1), 77-99.

Rando, T.A., 1993, Treatment of complicated mourning, Research Press, Champaign.

Range, L.M. \& Calhoun, L.G., 1990, 'Responses following suicide and other types of death: The perspective of the bereaved', Omega: The Journal of Death and Dying 21(4), 311-320.

Ratnarajah, D. \& Schofield, M.J., 2007, 'Parental suicide and its aftermath: A review', Journal of Family Studies 13, 78-93.

Ratnarajah, D. \& Schofield, M.J., 2008, 'Survivors' narratives of the impact of parental suicide', Suicide and Life-Threatening Behavior 38(5), 618-630.

Rohleder, P. \& Gibson, K., 2006, “"We are not fresh": HIVpositive women talk of their experience of living with their "spoiled identity"', South African Journal of Psychology 36(1), 25-44.

Rosenfeld, L. \& Prupas, M., 1984, Left alive: After a suicide death in the family, Charles C. Thomas, Springfield.

Rubey, C.T. \& Clark, D.C., 1987, 'Suicide survivors and the clergy', in E.J. Dunne, J.L. McIntosh \& K. Dunne-Maxim (eds.), Suicide and its aftermath: Understanding and counseling the survivors, pp. 151-158, Norton, New York.

Schlebusch, L., 2005, Suicidal behaviour in South Africa, University of KwaZulu-Natal Press, Scottsville.

Schurink, E.M., 1998, 'Designing qualitative research', in A.S. De Vos (ed.), Research at grass roots: A primer for the caring professions, pp. 252-264, JL van Schaik, Pretoria.

Seeber, L., 2002, 'The grief process after teenage suicide: An alternative', MA (Marriage and family therapy) dissertation, School of Behavioural Science, Potchefstroom University of Higher Christian Education.
Silverman, E., Range, L. \& Overholser, J., 1994-1995, 'Bereavement from suicide as compared to other forms of bereavement', Omega: The Journal of Death and Dying 30(1), 41-51.

Smith, J.A., 2003, 'Validity and qualitative psychology', in J.A. Smith (ed.), Qualitative psychology: A practical guide to research methods, pp. 232-235, Sage, London.

Springgay, S., 2002, 'Arts-based research as an uncertain text', CD-ROM, The Alberta Journal of Educational Research 48(3).

Stillion, J.M. \& McDowell, E.E., 1996, Suicide across the life span: Premature exits, 2nd edn., Taylor \& Francis, Washington.

Sudak, H., Maxim, K. \& Carpenter, M., 2008, 'Suicide and stigma: A review of the literature and personal reflections', Academic Psychiatry 32(2), 136-142.

Sveen, C. \& Walby, F.A., 2008, 'Suicide survivors' mental health and grief reactions: A systematic review of controlled studies', Suicide and Life-Threatening Behavior 38(1), 13-29.

Theron, L.C. \& Gilgun, F., 2009, 'Strangers, patients, monsters, jailers, or children: How South African caregivers view their partners with manganese poisoning', South African Journal of Psychology 39(2), 220-230.

Thom, D.P., Louw, A.E., Van Ede, D.M. \& Ferns, I., 1998, 'Adolescence', in D.A. Louw, D.M. Van Ede \& A.E. Louw, A.E. (eds.), Human development, pp. 383-468, Kagiso Tertiary, Cape Town.

Turner, de S., 2003, 'Horizons revealed: From methodology to method', International Journal of Qualitative Methods, viewed 28 March 2003, from http://www.ualberta.ca/ iiqm/ backissues/2_1/ html/turner.html

Ulmer, A., Range, L.M. \& Smith, P.C., 1991, 'Purpose in life: A moderator of recovery from bereavement', Omega: The Journal of Death and Dying 23(4), 279-289.

Watson, W.L. \& Lee, D., 1993, 'Is there life after suicide? The systemic belief approach for "survivors of suicide", Archives of Psychiatric Nursing 7(1), 37-43.

Webb, N.B., 1986, 'Before and after suicide: A preventive outreach program for colleges', Suicide and Life-Threatening Behavior 16(4), 469-480.

Wertheimer, A., 1991, A special scar: The experiences of people bereaved by suicide, Routledge, London.

Wertz, F.J., 1985, 'Method and findings in a phenomenological study of a complex life-event: Being criminally victimized', in A. Giorgi (ed.), Phenomenology and psychological research, pp. 155-216, Duquesne University Press, Pittsburgh. 